\title{
ALGORITMA PREDIKAT PEGAWAI DENGAN TIGA VARIABEL MENGGUNAKAN FUZZY INFERENCE SYSTEM TSUKAMOTO
}

\author{
Ahmad Makih \\ Magister Sistem Informasi, Universitas Gunadarma \\ Jl. Margonda Raya No.100, Pondok Cina, Beji \\ Kota Depok, Jawa Barat 16424
}

\begin{abstract}
Abstrak
Dalam kehidupan sehari-hari kita sering menemukan beberapa hal yang tidak dapat kita jelaskan ukurannya secara tepat, seperti tingkat kebaikan seseorang, tingkat kebahagian seseorang dll. Dalam hal ini juga berkaitan dengan kinerja suatu pegawai baik atau buruknya tidak ada yang mampu mengukur secara akurat apakah pegawai tersebut benar berkinerja baik atau sebaliknya, oleh karena itu kita dapat memanfaatkan logika fuzzy. Sistem fuzzy adalah sebuah sistem yang dibangun dengan definisi, cara kerja, dan deskripsi yang jelas yang berdasar pada teori logic fuzzy. Sedangkan Inference System adalah aturan dalam alogirtma fuzzy dengan menggunakan If - else. Dan metode Tsukamoto merupakan hasil dari logic fuzzy yang didefuzzyfikasikan. Pada kasus ini adalah predikat mengenai baik atau tidaknya sebuah pegawai. Dalam penelitian ini menggunakan 3 variabel sebagai parameter logic fuzzy yaitu Hasil Produksi, Produk NG dan Absensi.

In everyday life we often find a number of things that we cannot explain their exact size, such as a person's level of goodness, happiness etc. In this case, it is also related to the performance of an employee, good or bad, no one is able to accurately measure whether the employee is performing well or vice versa, therefore we can use fuzzy logic. Fuzzy systems are systems that are built with definitions, ways of working, and clear descriptions based on fuzzy logic. While the Inference System is a rule in fuzzy alogirts by using If - else. And the Tsukamoto method is the result of fuzzy logic that is defined. In this case, it is a predicate regarding whether or not an employee is good. In this study using 3 variables as fuzzy logic parameters, namely Products Results, NG Products and Attendance.
\end{abstract}

Kata Kunci: System, Fuzzy, Inference, Tsukamoto, Employee.

\section{Pendahuluan}

Konsep sistem pendukung keputusan yang berbasis komputer (Computer Based Decision Support System) saat ini semakin berkembang. Banyak metode yang digunakan untuk membantu dalam proses pendukung pengambilan keputusan. Pengambilan keputusan dilakukan dengan pendekatan sistematis terhadap permasalahan melalui proses pengumpulan data menjadi informasi serta ditambah dengan faktor-faktor yang perlu dipertimbangkan dalam pengambilan keputusan. Oleh karena itu, aplikasi sistem pendukung keputusan perlu diterapkan dalam kehidupan sehari-hari yang berguna untuk mengurangi subyektivitas dari pengambil keputusan serta menghindari kesalahan dalam melakukan pengambilan keputusan.

\section{Metode Penelitian}

Teknik pengumpulan data dalam rangka pengumpulan informasi mengenai objek penelitian ini, yaitu: 
1. Observasi

Observasi yaitu melakukan pengamatan langsung di Departemen Produksi Press pada PT Nandya Karya Perkasa dengan menggunakan daftar ceklis. Hasil dari pengamatan yang dilakukan menjadi landasan penulis dalam melakukan pengembangan sistem yang akan dibuat.

2. Wawancara

Metode wawancara adalah metode pengumpulan data melalui tanya jawab secara langsung kepada pihak-pihak yang terkait dengan obyek penelitian. Pihak yang diwawancarai adalah Kepala Regu, Kepala Seksi dan Operator Produksi di Departemen Produksi Press dan khususnya operator yang terlibat di dalam produksi Plate L Cover.

3. Sampling

Melakukan pemilihan item part tertentu dari seluruh item part yang ada dengan tujuan mempelajari sebagian item part tersebut untuk mewakili seluruh itemnya, yaitu Plate L Cover.

4. Studi Pustaka

Studi pustaka yaitu metode pengumpulan data dengan melakukan pencarian referensi yang berkaitan dengan framework Codeigniter, database MySQL, dan Teori Fuzzy Inference System (FIS) Tsukamoto dari berbagai referensi, baik itu referensi elektronik yang didapat dari internet maupun referensi dari buku teks. Referensi yang diperoleh, kemudian dikaji sebagai dasar penulis dalam menyelesaikan penelitian.

\section{Fuzzy Inference System (Tsukamoto)}

Ada beberapa tahapan dalam menyelesaikan metode Fuzzy Inference System yaitu:

\subsection{Mendefinisikan Variabel (Fuzzyfikasi)}

Pengambilan variabel fuzzy terhadap kinerja pegawai berdasarkan kualitas, kuantitas, tanggung jawab dan pelaksanaan tugas (Mangkunegara, 2009), oleh karena itu maka didapatkan variabel fuzzy sebagai berikut:

1. Hasil Produksi

Dalam hal ini, data yang digunakan adalah hasil produksi tertinggi (max), titik tengah hasil produksi ( $\mathrm{mid}$ ) dan hasil produksi terendah oleh pegawai (min) berdasarkan laporan produksi harian pegawai.

2. Produk NG 
Dalam hal ini, data yang digunakan adalah hasil produk NG tertinggi (max) dan hasil produk NG terendah (min) berdasarkan data produksi part repair (masuk).

3. Absensi

Dalam hal ini, data yang digunakan adalah absensi karyawan tertinggi (max) dan absensi karyawan terendah ( $\mathrm{min}$ ) berdasarkan rekap absensi karyawan.

4. Kemampuan Produksi

Dalam hal ini, data yang digunakan adalah kemampuan produksi tertinggi (max) dan kemampuan produksi terendah $(\mathrm{min})$ berdasarkan laporan pencapaian produksi.

Tabel 1. Model Base Fuzzy Tsukamoto

\begin{tabular}{|c|c|c|}
\hline No. & Fragment Variabel & Keterangan \\
\hline 1. & $\mathrm{~W}_{\max }$ & Data produksi maksimum \\
\hline 2. & $\mathrm{~W}_{\mathrm{t}}$ & Titik tengah data produksi \\
\hline 3. & $\mathrm{w}_{\min }$ & Data produksi minimum \\
\hline 4. & $\mathrm{X}_{\max }$ & Data NG maksimum \\
\hline 5. & $\mathrm{x}_{\min }$ & Data NG minimum \\
\hline 6. & $\mathrm{y}_{\max }$ & Data absen maksimum \\
\hline 7. & $\mathrm{y}_{\min }$ & Data absen minimum \\
\hline 8. & $Z_{\max }$ & Data kemampuan produksi maksimum \\
\hline 9. & $Z_{\min }$ & Data kemampuan produksi minimum \\
\hline 10. & $\mu \_\mathrm{w}$ ttinggi[w] & Nilai keanggotaan tinggi dari variabel produksi \\
\hline 11. & $\mu \_\mathrm{w} \_$normal[w] & Nilai keanggotaan normal dari variabel produksi \\
\hline 12. & $\mu \_\mathrm{w} \_$rendah $[\mathrm{w}]$ & Nilai keanggotaan rendah dari variabel produksi \\
\hline 13. & $\mu \_\mathrm{x} \_$banyak $[\mathrm{x}]$ & Nilai keanggotaan banyak dari variabel NG \\
\hline 14. & $\mu \_\mathrm{x} \_$sedikit$[\mathrm{x}]$ & Nilai keanggotaan sedikit dari variabel NG \\
\hline 15. & $\mu \_y \_$rajin[y] & Nilai keanggotaan rajin dari variabel absen \\
\hline 16. & $\mu \_\mathrm{y} \_$biasa[y] & Nilai keanggotaan biasa dari variabel absen \\
\hline 17. & $\mu \_z \_$baik $[z]$ & $\begin{array}{l}\text { Nilai keanggotaan baik dari variabel kemampuan } \\
\text { produksi }\end{array}$ \\
\hline 18. & $\mu \_z \_b u r u k[z]$ & $\begin{array}{l}\text { Nilai keanggotaan } \\
\text { kemampuan produksi }\end{array}$ \\
\hline 19. & $\alpha 1$ & $\alpha$ dari aturan fuzzy $[\mathrm{R} 1]$ \\
\hline 20. & $\alpha 2$ & $\alpha$ dari aturan fuzzy [R2] \\
\hline 21. & $\alpha 3$ & $\alpha$ dari aturan fuzzy [R3] \\
\hline 22. & $\alpha 4$ & $\alpha$ dari aturan fuzzy [R4] \\
\hline 23. & $\alpha 5$ & $\alpha$ dari aturan fuzzy [R5] \\
\hline 24. & $\alpha 6$ & $\alpha$ dari aturan fuzzy [R6] \\
\hline 25. & $\alpha 7$ & $\alpha$ dari aturan fuzzy [R7] \\
\hline 26. & $\alpha 8$ & $\alpha$ dari aturan fuzzy [R8] \\
\hline 27. & $\alpha 9$ & $\alpha$ dari aturan fuzzy [R9] \\
\hline 28. & $\alpha 10$ & $\alpha$ dari aturan fuzzy [R10] \\
\hline 29. & $\mathrm{z} 1$ & Nilai z dari aturan fuzzy [R1] \\
\hline 30. & $\mathrm{z} 2$ & Nilai z dari aturan fuzzy [R2] \\
\hline
\end{tabular}




\begin{tabular}{|l|l|l|}
\hline No. & \multicolumn{1}{|c|}{ Variabel } & \multicolumn{1}{c|}{ Keterangan } \\
\hline 31. & z3 & Nilai z dari aturan $f u z z y[R 3]$ \\
\hline 32. & z4 & Nilai z dari aturan $f u z z y[R 4]$ \\
\hline 33. & z5 & Nilai z dari aturan $f u z z y[R 5]$ \\
\hline 34. & z6 & Nilai z dari aturan fuzzy [R6] \\
\hline 35. & z7 & Nilai z dari aturan $f u z z y[R 7]$ \\
\hline 36. & z8 & Nilai z dari aturan fuzzy [R8] \\
\hline 37. & z9 & Nilai z dari aturan fuzzy [R9] \\
\hline 38. & z10 & Nilai z dari aturan fuzzy [R10] \\
\hline 40. & W & Input variabel produksi \\
\hline 41. & $\mathrm{x}$ & Input variabel NG \\
\hline 42. & $\mathrm{y}$ & Input variabel absen \\
\hline 43. & $\mathrm{Z}$ & $\begin{array}{l}\text { Output Kinerja Produksi berdasarkan Fuzzy } \\
\text { Inference System Tsukamoto }\end{array}$ \\
\hline
\end{tabular}

\subsection{Himpunan Fuzzy dan Fungsi Keanggotaan}

1. Hasil Produksi

Pengambilan data berdasarkan Laporan Produksi Harian Pegawai, maka didapatkan nilai min, max dan mid yaitu:

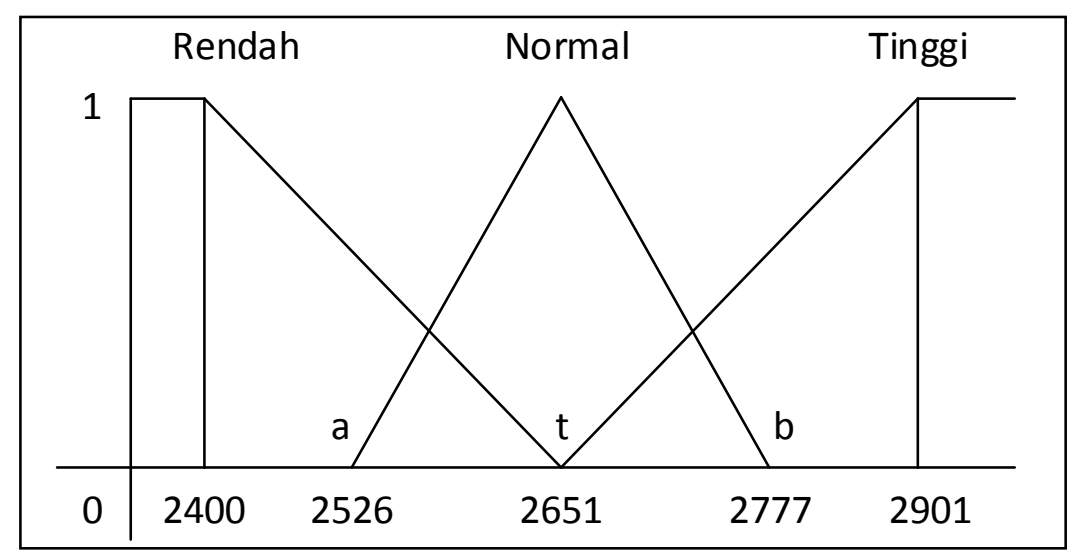

Gambar 1. Bentuk Himpunan Fuzzy Hasil Produksi

Data tertinggi $=2901$

Data terendah $=2400$

Titik t $=(2901-2400) / 2=250.5+2400=2650.5($ dibulatkan 2651)

Titik a $=(2651-2400) / 2=125.5+2400=2525.5($ dibulatkan 2526$)$

Titik b $\quad=(2901-2651) / 2=125.5+2651=2776.5($ dibulatkan 2777$)$

Lalu dimasukkan ke dalam fungsi keanggotaan berdasarkan persamaan linear naik, karena variabel hasil produksi memiliki karakteristik yang sesuai dengan persamaan linear naik yaitu semakin tinggi nilai variabel maka akan semakin baik begitu pula sebaliknya: 
a. Produksi $($ Rendah $)=\{2400-2651\}$

$$
\mu \_\mathrm{w} \_ \text {rendah }[\mathrm{w}]=\left\{\begin{array}{cc}
1, & w \leq 2400 \\
\frac{2651-w}{251}, & 2400 \leq w \leq 2651 \\
0, & w \geq 2651
\end{array}\right.
$$

b. Produksi $($ Normal $)=\{2526-2777\}$

$$
\mu_{-}{ }_{-} \_ \text {normal }[\mathrm{w}]=\left\{\begin{array}{cc}
0, & w \leq 2526 \\
\frac{w-2526}{125}, & 2526 \leq w \leq 2651 \\
\frac{2651-w}{126}, & 2651 \leq w \leq 2777 \\
0, & w \geq 2777
\end{array}\right.
$$

c. Produksi $($ Tinggi $)=\{2651-2901\}$

$$
\mu \_\mathrm{w} \_ \text {tinggi }[\mathrm{w}]=\left\{\begin{array}{cc}
0, & w \leq 2651 \\
\frac{w-2651}{250}, & 2651 \leq w \leq 2901 \\
1, & w \geq 2901
\end{array}\right.
$$

2. Produk NG

Pengambilan data berdasarkan Data Produksi Part Repair (Masuk), maka didapatkan nilai max, min, dan mid yaitu:

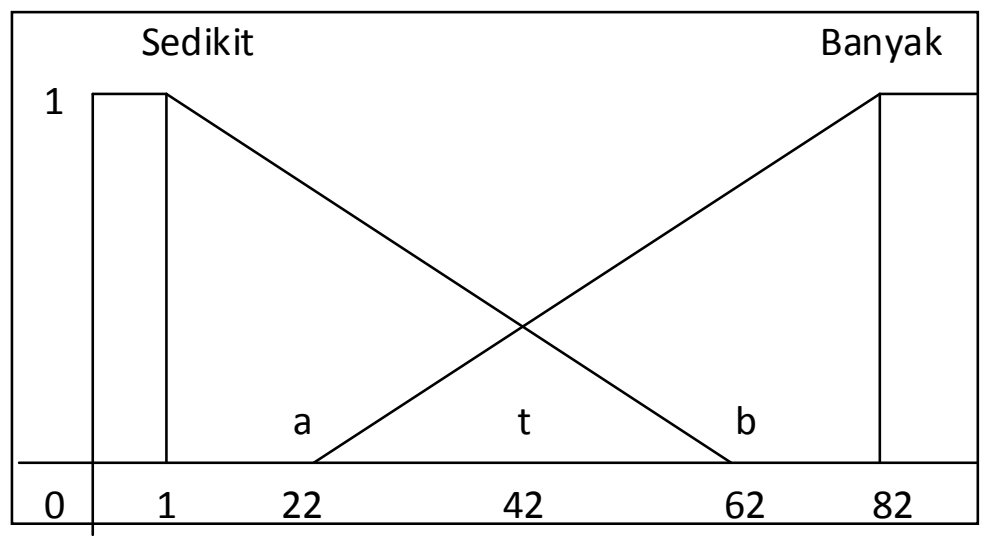

Gambar 2. Bentuk Himpunan Fuzzy Produk NG

Data tertinggi $=82$

Data terendah $=1$

Titik $\mathrm{t}=(82-1) / 2=40.5+1=41.5($ dibulatkan 42$)$

Titik a $=(42-1) / 2=20.5+1=21.5($ dibulatkan 22$)$

Titik b $\quad=(82-42) / 2=20+42=62$ 
Lalu dimasukkan ke dalam fungsi keanggotaan berdasarkan persamaan linear turun, karena variabel produk NG memiliki karakteristik yang sesuai dengan persamaan linear turun yaitu semakin rendah nilai variabel maka akan semakin baik begitu pula sebaliknya:

a. $\quad$ NG (Sedikit) $=\{1-62\}$

$$
\mu \_x \_ \text {sedikit }[\mathrm{x}]=\quad\left\{\begin{array}{cc}
1, & x \leq 1 \\
\frac{62-x}{61}, & 1 \leq x \leq 62 \\
0, & x \geq 62
\end{array}\right.
$$

b. $\quad$ NG (Banyak) $=\{22-82\}$

$$
\mu \_\mathrm{x} \_ \text {banyak }[\mathrm{x}]=\left\{\begin{array}{cc}
0, & x \leq 22 \\
\frac{x-22}{60}, & 22 \leq x \leq 82 \\
1, & x \geq 82
\end{array}\right.
$$

3. Absensi

Pengambilan data berdasarkan Absensi Karyawan, maka didapatkan nilai max, min, dan mid yaitu:

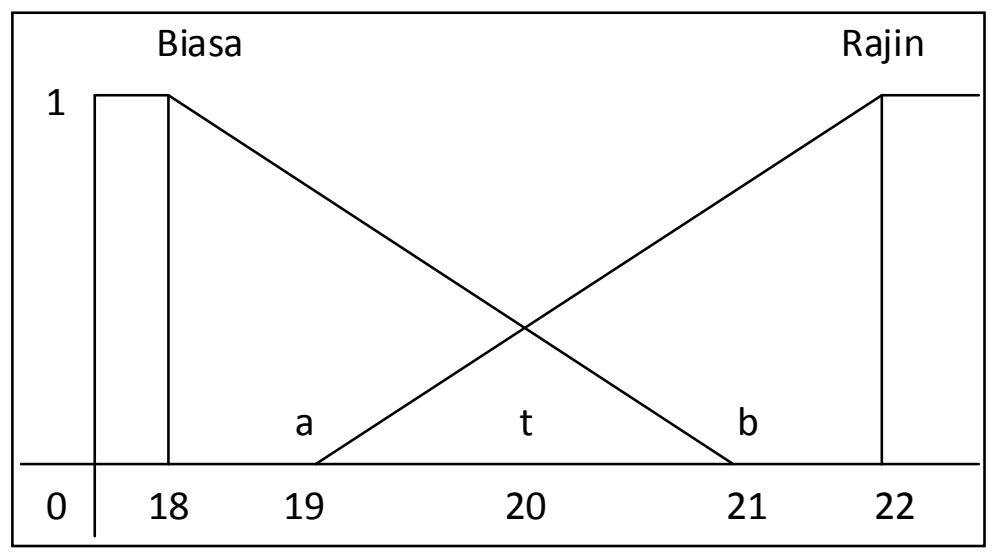

Gambar 3. Bentuk Himpunan Fuzzy Absensi

Data tertinggi $=22$

Data terendah $=18$

Titik $\mathrm{t}=(22-18) / 2=2+18=20$

Titik a $=(20-18) / 2=1+18=19$

Titik b $\quad=(22-20) / 2=1+20=21$

Lalu dimasukkan ke dalam fungsi keanggotaan berdasarkan persamaan linear naik, karena variabel absensi memiliki karakteristik yang sesuai dengan persamaan linear 
naik yaitu semakin tinggi nilai variabel maka akan semakin baik begitu pula sebaliknya:

a. Absen (Biasa) $=\{18-21\}$

$$
\mu \_y \_b i a s a[y]=\left\{\begin{array}{cc}
1, & y \leq 18 \\
\frac{21-y}{3}, & 18 \leq y \leq 21 \\
0, & y \geq 21
\end{array}\right.
$$

b. Absen (Rajin) $=\{19-22\}$

$$
\mu \_ \text {y_rajin[y] }=\left\{\begin{array}{cc}
0, & y \leq 19 \\
\frac{y-19}{3}, & 19 \leq y \leq 22 \\
1, & y \geq 22
\end{array}\right.
$$

4. Kemampuan Produksi

Pengambilan data berdasarkan Rekap Pencapaian Produksi Press dengan nilai max $100 \%$ dan $\min 72 \%$ seperti pada gambar berikut:

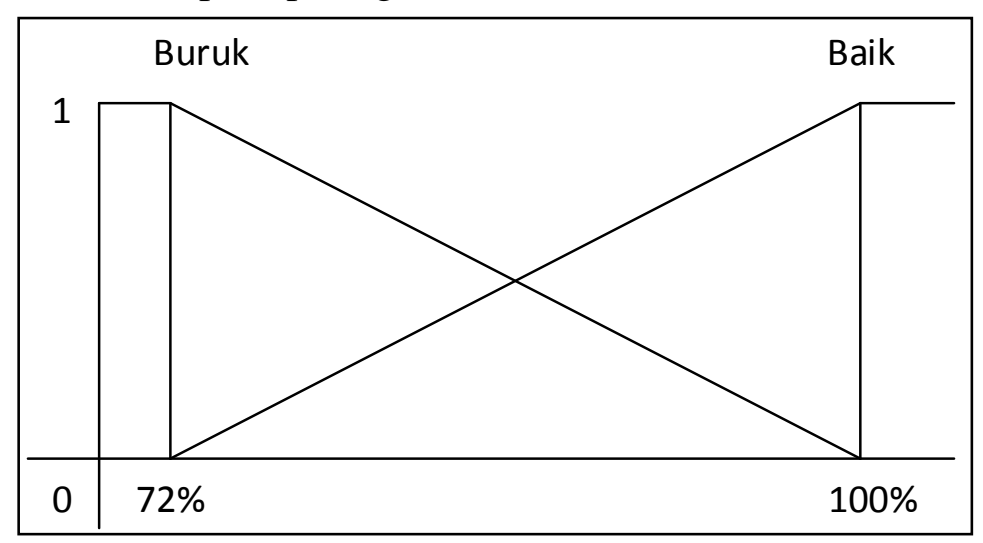

Gambar 4. Bentuk Himpunan Fuzzy Kemampuan Produksi

Variabel kemampuan produksi memiliki karaketristik yang berbeda dari tiga variabel sebelumnya (hasil produksi, produk NG dan absensi). Jika ketiga variabel tersebut akan menjadi "dasar" dari aturan fuzzy, maka variabel kemampuan produksi akan menjadi "hasil nilai" dari aturan-aturan yang dibuat oleh ketiga variabel sebelumnya. Jika ada aturan fuzzy ke-n $\left(\alpha_{n}\right)$ maka "hasil nilai" aturan $\left(z_{n}\right)$ juga berjumlah $n$ dengan output sesuai dengan variabel kemampuan produksi yaitu berupa persentasi $72 \%$ hingga $100 \%$ sesuai dengan data pencapaian produksi.

a. Kemampuan Produksi (Baik) $=\{100 \%\}$

$\mu \_z \_$baik $[z]=\left(z \_\right.$buruk $\left.+z_{n}\left(z \_b a i k-z \_b u r u k\right)\right)$ 


$$
\left(72 \%+z_{n}(100 \%-72 \%)\right.
$$

b. Kemampuan Produksi (Buruk) $=\{72 \%\}$

$$
\begin{aligned}
\mu \_z \_b u r u k[z]= & \left(z \_b a i k-z_{n}\left(z \_b a i k-z \_b u r u k\right)\right) \\
& \left(100 \%-z_{n}(100 \%-72 \%)\right.
\end{aligned}
$$

\subsection{Inferensi Variabel Tsukamoto}

Dengan mengkombinasikan himpunan-himpunan fuzzy tersebut, maka diperoleh sepuluh aturan fuzzy sebagai berikut:

[R1] IF Produksi Tinggi and NG Sedikit Then Kemampuan Produksi Baik

[R2] IF Produksi Tinggi and NG Banyak Then Kemampuan Produksi Buruk

[R3] IF Produksi Normal and NG Sedikit Then Kemampuan Produksi Baik

[R4] IF Produksi Normal and NG Banyak Then Kemampuan Produksi Buruk

[R5] IF Produksi Rendah and NG Sedikit Then Kemampuan Produksi Buruk

[R6] IF Produksi Rendah and NG Banyak Then Kemampuan Produksi Buruk

[R7] IF Absen Rajin and NG Sedikit Then Kemampuan Produksi Baik

[R8] IF Absen Rajin and NG Banyak Then Kemampuan Produksi Buruk

[R9] IF Absen Biasa and NG Sedikit Then Kemampuan Produksi Baik

[R10] IF Absen Biasa and NG Banyak Then Kemampuan Produksi Buruk

\subsection{Defuzifikasi}

Pada metode Tsukamoto, untuk menentukan output pendukung keputusan terhadap kinerja pegawai, maka digunakan defuzifikasi rata-rata terpusat, yaitu:

$$
\mathrm{Z}=\frac{\alpha 1^{*} \mathrm{z} 1+\alpha 2^{*} \mathrm{z} 2+\alpha 3^{*} \mathrm{z} 3+\alpha 4^{*} \mathrm{z} 4+\alpha .5 * \mathrm{z} 5+\alpha 6^{*} \mathrm{z} 7+\alpha .8 * \mathrm{z} 8+\alpha .9 * \mathrm{z} 9+\alpha 10^{*} \mathrm{z} 10}{\alpha 1+\alpha 2+\alpha 3+\alpha 4+\alpha .5+\alpha .6+\alpha 7+\alpha 8+\alpha 9+\alpha 10}
$$

\section{Kasus Penyelesaian dengan FIS Tsukamoto}

Seorang pegawai produksi dengan NIK (Nomor Induk Karyawan) 480 bernama Arief Badarudin melakukan produksi part. Sample data diambil berdasarkan Absensi Karyawan, Laporan Produksi Harian Pegawai dan Data Produksi Part Repair:
Absensi
: 19 Hari
Hasil Produksi : Rata-rata 2793 Part
Produk NG : : Rata- rata 51 Part 
Lalu, Kepala Departemen Produksi ingin mengetahui kinerja pegawai produksi tersebut, maka digunakan penyelesaian menggunakan Fuzzy Inference System Tsukamoto. Untuk nilai himpunan fuzzy, fungsi keanggotaan, inferensi dan defuzifikasi menggunakan penjelasan (Himpunan Fuzzy dan Fungsi Keanggotaan, Inferensi Variabel Tsukamoto serta Defuzifikasi)

1. Himpunan Fuzzy dan Fungsi Keanggotaan

a. Absen Rajin

Diketahui Absensi: 19 Hari

u_y_rajin[y] $=\left\{\begin{array}{cc}0, & y \leq 19 \\ \frac{y-19}{3}, & 19 \leq y \leq 22 \\ 1, & y \geq 22\end{array}\right.$

Kemudian isikan nilai y dengan angka 19, maka didapatkan hasil:

19 bukan dari $\leq 19$ maka nilai tidak 0

19 bukan dari $\geq 22$ maka nilai tidak 1

19 bagian dari $\leq 19 \mathrm{y} \leq 22,(19-19) / 3=0$

Maka nilai 19 adalah 0

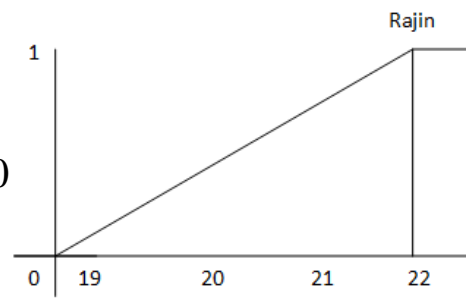

b. Absen Biasa

Diketahui Absensi: 19 Hari

M_y_biasa[y] $=$

$$
\left\{\begin{array}{cc}
1, & y \leq 18 \\
\frac{21-y}{3}, & 18 \leq y \leq 21 \\
0, & y \geq 21
\end{array}\right.
$$

Kemudian isikan nilai y dengan angka 19, maka didapatkan hasil:

19 bukan dari $\leq 18$ maka nilai tidak 1

19 bukan dari $\geq 21$ maka nilai tidak 0

19 bagian dari $\leq 18 \mathrm{y} \leq 21,(21-19) / 3=0.66$

Maka nilai 19 adalah 0.66

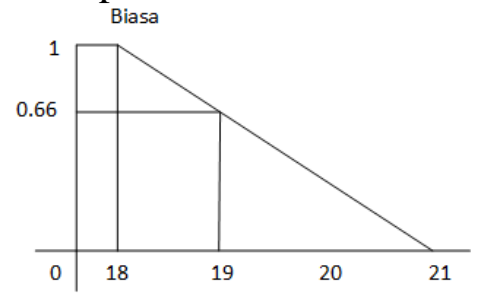

c. Produksi Tinggi

Diketahui Hasil Produksi: 2793 Part

$$
\text { H_w_tinggi }[w]=\left\{\begin{array}{cc}
0, & w \leq 2651 \\
\frac{w-2651}{250}, & 2651 \leq w \leq 2901 \\
1, & w \geq 2901
\end{array}\right.
$$

Kemudian isikan nilai w dengan angka 2793, maka didapatkan hasil:

2793 bukan dari $\leq 2651$ maka nilai tidak 0 
2793 bukan dari $\geq 2901$ maka nilai tidak 1

2793 bagian dari $\leq 2651 \mathrm{w} \leq 2901$,

$\operatorname{Maka}(2793-2651) / 250=0.57$

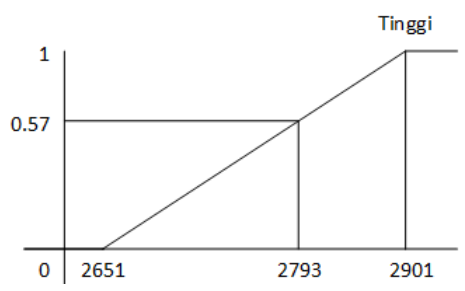

d. Produksi Normal $\quad\left(\begin{array}{l}0, \quad w \leq 2526\end{array}\right.$

$\mu \_\mathrm{w} \_$normal $[\mathrm{w}]=\left\{\begin{array}{cc}\frac{w-2526}{125}, & 2526 \leq w \leq 2651 \\ \frac{2651-w}{126}, & 2651 \leq w \leq 2777 \\ 0, & w \geq 2777\end{array}\right.$

Kemudian isikan nilai w dengan angka 2793, maka didapatkan hasil:

2793 bukan dari $\leq 2526$ maka nilai tidak 0

2793 bagian dari $\geq 2777$ maka nilai 0

2793 bukan dari $\leq 2526 \mathrm{w} \leq 2651$

2793 bukan dari $\leq 2651 \mathrm{w} \leq 2777$

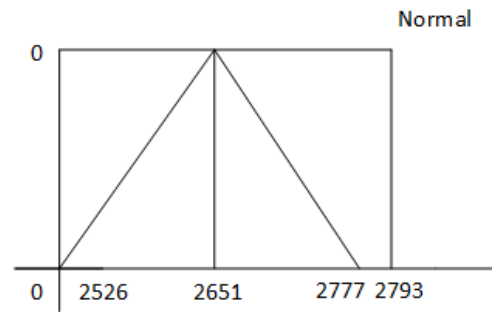

Maka nilai 2793 adalah 0

e. Produksi Rendah

Diketahui Hasil Produksi: 2793 Part

$\mu_{-} \mathrm{w}_{-}$rendah $[\mathrm{w}]=\left\{\begin{array}{cc}1, & w \leq 2400 \\ \frac{2651-w}{251}, & 2400 \leq w \leq 2651 \\ 0, & w \geq 2651\end{array}\right.$

Kemudian isikan nilai w dengan angka 2793, maka didapatkan hasil:

2793 bukan dari $\leq 2400$ maka nilai tidak 1

2793 bagian dari $\geq 2651$ maka nilainya 0

2793 bukan dari antara 2400 sampai 2651

Maka nilai 2793 adalah 0

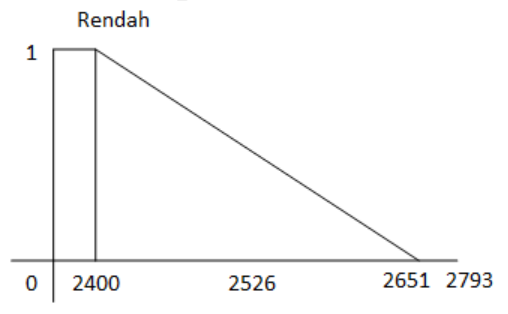

f. NG Sedikit

Diketahui Produk NG: 51 Part

$\mu \_x \_$sedikit $[\mathrm{x}]=$

$$
\left\{\begin{array}{cl}
\frac{1,}{62-x} & x \leq 1 \\
61 & 1 \leq x \leq 62 \\
0, & x \geq 62
\end{array}\right.
$$

Kemudian isikan nilai x dengan angka 51, maka didapatkan hasil:

51 bukan dari $\leq 1$ maka nilai tidak 1

51 bukan dari $\geq 62$ maka nilai tidak 0

51 bagian dari $\leq 1 \mathrm{x} \leq 62$, $(62-51) / 61=0.18$

Maka nilai 51 adalah 0.18

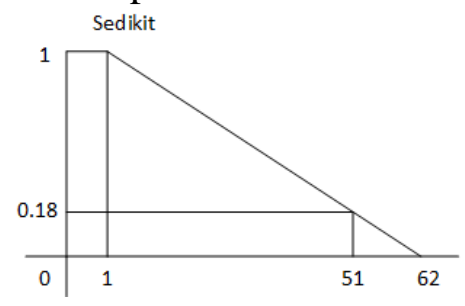


g. NG Banyak

Diketahui Produk NG: 51 Part

$\mu \_\mathrm{x} \_$banyak $[\mathrm{x}]=\quad\left\{\begin{array}{cc}0, & x \leq 22 \\ \frac{x-22}{60}, & 22 \leq x \leq 82 \\ 1, & x \geq 82\end{array}\right.$

Kemudian isikan nilai $\mathrm{x}$ dengan angka 51, maka didapatkan hasil:

51 bukan dari $\leq 22$ maka nilai tidak 0

51 bukan dari $\geq 82$ maka nilai tidak 1

51 bagian dari $\leq 22 \mathrm{x} \leq 82,(51-22) / 60=0.48$

Maka nilai 51 adalah 0.48

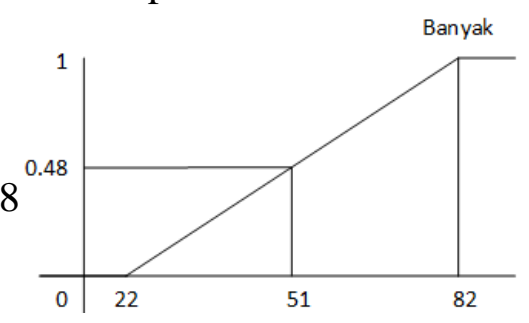

Maka didapatkan keseluruhan nilai kederajatan pada fungsi keanggotaan yaitu:

Tabel 2. Nilai Kederajatan

\begin{tabular}{|l|c|}
\hline \multicolumn{1}{|c|}{ Variabel } & Nilai Kederajatan \\
\hline Absen Rajin & 0 \\
\hline Absen Biasa & 0.66 \\
\hline Produksi Tinggi & 0.57 \\
\hline Produksi Normal & 0 \\
\hline Produksi Rendah & 0 \\
\hline NG Banyak & 0.48 \\
\hline NG Sedikit & 0.18 \\
\hline
\end{tabular}

2. Inferensi Variabel Tsukamoto

a. [R1] IF Produksi Tinggi and NG Sedikit Then Kemampuan Produksi Baik

Karena menggunakan "and” maka diambil nilai min (0.57 dan 0.18$)$

Kemampuan Produksi (Baik) $=100 \%$

M_z_baik [z] $=(72 \%+0.18(100 \%-72 \%)=77.04$

b. [R2] IF Produksi Tinggi and NG Banyak Then Kemampuan Produksi Baik

Karena menggunakan "and" maka diambil nilai min (0.57 dan 0.48$)$

Kemampuan Produksi (Buruk) $=72 \%$

H_z_baik [z] $=(100 \%-0.48(100 \%-72 \%)=86.56$

c. [R3] IF Produksi Normal and NG Sedikit Then Kemampuan Produksi Baik

Karena menggunakan "and" maka diambil nilai min (0 dan 0.18$)$

Kemampuan Produksi (Baik) $=100 \%$

M_z_baik [z] $=(72 \%+0(100 \%-72 \%)=72$

d. [R4] IF Produksi Normal and NG Banyak Then Kemampuan Produksi Buruk

Karena menggunakan "and" maka diambil nilai min (0 dan 0.52$)$

Kemampuan Produksi (Buruk) $=72 \%$ 
M_z_buruk $[\mathrm{z}]=(100 \%-0(100 \%-72 \%)=100$

e. [R5] IF Produksi Rendah and NG Sedikit Then Kemampuan Produksi Buruk

Karena menggunakan "and" maka diambil nilai min (0 dan 0.18 )

Kemampuan Produksi (Buruk) $=72 \%$

M_z_buruk $[\mathrm{z}]=(100 \%-0(100 \%-72 \%)=100$

f. [R6] IF Produksi Rendah and NG Banyak Then Kemampuan Produksi Buruk

Karena menggunakan "and" maka diambil nilai min (0 dan 0.48$)$

Kemampuan Produksi (Buruk) $=72 \%$

$\mu \_z \_b u r u k[z]=(100 \%-0(100 \%-72 \%)=100$

g. [R7] IF Absen Rajin and NG Sedikit Then Kemampuan Produksi Baik

Karena menggunakan "and" maka diambil nilai min (0 dan 0.18 )

Kemampuan Produksi $($ Baik $)=100 \%$

H_z_baik $[\mathrm{z}]=(72 \%+0(100 \%-72 \%)=72$

h. [R8] IF Absen Rajin and NG Banyak Then Kemampuan Produksi Baik

Karena menggunakan "and" maka diambil nilai min (0 dan 0.48)

Kemampuan Produksi (Buruk) $=100 \%$

M_z_baik [z] $=(100 \%-0(100 \%-72 \%)=100$

i. [R9] IF Absen Biasa and NG Sedikit Then Kemampuan Produksi Buruk

Karena menggunakan "and” maka diambil nilai min (0.66 dan 0.18)

Kemampuan Produksi $($ Baik $)=72 \%$

M_z_buruk [z] $=(72 \%+0.18(100 \%-72 \%)=77.04$

j. [R10] IF Absen Biasa and NG Banyak Then Kemampuan Produksi Buruk

Karena menggunakan “and” maka diambil nilai min (0.66 dan 0.48)

Kemampuan Produksi (Buruk) $=72 \%$

$\mu \_z \_b u r u k[z]=(100 \%-0.48(100 \%-72 \%)=86.56$

Maka keseluruhan hasil inferensi dan hasil nilai inferensi berdasarkan sepuluh aturan dengan tiga variabel dasar (variabel hasil produksi, produk NG dan absensi) yaitu:

Tabel 3. Hasil Inferensi dan Hasil Nilai Inferensi Tsukamoto

\begin{tabular}{|c|c|c|c|}
\hline \multicolumn{2}{|c|}{ Hasil Inferensi } & \multicolumn{2}{c|}{ Hasil Nilai Inferensi } \\
\hline$\alpha 1$ & 0.18 & $\mathrm{z} 1$ & 77.04 \\
\hline$\alpha 2$ & 0.48 & $\mathrm{z} 2$ & 86.56 \\
\hline$\alpha 3$ & 0 & $\mathrm{z} 3$ & 72 \\
\hline$\alpha 4$ & 0 & $\mathrm{z} 4$ & 100 \\
\hline$\alpha 5$ & 0 & $\mathrm{z} 5$ & 100 \\
\hline
\end{tabular}




\begin{tabular}{|c|c|c|c|}
\hline$\alpha 6$ & 0 & $\mathrm{z} 6$ & 100 \\
\hline$\alpha 7$ & 0 & $\mathrm{z} 7$ & 72 \\
\hline$\alpha 8$ & 0 & $\mathrm{z} 8$ & 100 \\
\hline$\alpha 9$ & 0.18 & $\mathrm{z} 9$ & 77.04 \\
\hline$\alpha 10$ & 0.48 & $\mathrm{z} 10$ & 86.56 \\
\hline
\end{tabular}

\section{Defuzifikasi}

Setelah mendapatkan hasil inferensi dan hasil nilai inferensi, langkah selanjutnya adalah melakukan perhitungan defuzifikasi rata-rata terpusat.

$Z=\frac{(0.18 * 77.04)+(0.48 * 86.56)+(0 * 72)+(0 * 100)+(0 * 100)+(0 * 100)+(0 * 72)+(0 * 100)+(0.18 * 77.04)+(0.48 * 86.56)}{0.18+0.48+0+0+0+0+0+0+0.18+0.48}$

$$
\begin{gathered}
\mathrm{Z}=\frac{13.8672+41.5488+0+0+0+0+0+0+13.8672+41.5488}{1.32} \\
Z=\quad 113.52 / 1.32=83.96 \%
\end{gathered}
$$

Maka berdasarkan perhitungan defuzifikasi rata-rata terpusat didapatkan nilai $\mathrm{Z}$ sebagai output penilaian kinerja pegawai produksi metode fuzzy inference system tsukamoto adalah $83.96 \%$.

Dapat disimpulkan dari penyelesaian kasus kinerja pegawai produksi dengan Absensi 19 hari, Hasil Produksi rata-rata 2973 part, Produk NG rata-rata 51 part. Maka pegawai bernama Arief mendapatkan predikat buruk dengan persentasi $83.96 \%$. Sesuai dengan standar produksi di Departemen Produksi Press $85 \%$ pada pencapaian produksi. Jika produksi dibawah $85 \%$, maka akan mendapatkan predikat buruk sedangkan jika sama dengan atau lebih dari $85 \%$, maka akan mendapat predikat baik.

\section{Kesimpulan dan Saran}

Bahwa dapat kita simpulkan penggunaan Alogritma Tiga Variabel Fuzzy Inference System Tsukamoto dengan objek pegawai, kita dapat mengetahui kinerja pegawai secara akurat dan terukur. Dengan adanya perhitungan logika fuzzy ini, dapat meningkatkan kinerja pegawai dalam melakukan produksi dan memonitoring aktivitas pegawai secara tepat dan cepat. Kemudian saran dari peneliti adalah bahwa agar perhitungan fuzzy ini dapat diterapkan juga di jenis part produksi lainnya. 


\section{Daftar Pustaka}

[1] Anzizhan, Syafarudin. 2004. Sistem Pengambilan Keputusan Pendidikan. Jakarta: Grasindo.

[2] Djalal, Nachrowi. 2004. Teknik Pengambilan Keputusan. Jakarta: Grasindo.

[3] Kusrini. 2010. Sistem Pakar, Teori dan Aplikasi. Yogyakarta: Andi.

[4] Kusumadewi dan Purnomo. 2004. Aplikasi Logika Fuzzy Untuk Mendukung Keputusan. Yogyakarta: Graha Ilmu.

[5] Marimin. 2004. Teknik dan Aplikasi Pengambilan Keputusan Kriteria Majemuk. Jakarta: Grasindo.

[6] Naba, Agus. 2009. Tutorial Cepat \& Mudah Fuzzy Logic Dengan Matlab. Yogyakarta: Andi.

[7] Nofriansyah, Dicky. 2014. Konsep Data Mining Vs Sistem Pendukung Keputusan. Yogyakarta: Deepublish.

[8] Sitorus, Lamhot. 2015. Algoritma dan Pemrograman, Yogyakarta: Andi.

[9] Timothy. 2016. Fuzzy Logic With Engineering Application. England. 